\title{
$\mathrm{K}_{2} \mathrm{NiF}_{4}$ 型 $\left(\mathrm{La}_{1-x} \mathrm{Sr}_{x}\right)_{2} \mathrm{MnO}_{4}$ の合成とその電気的特性
}

\author{
下野 功・小西 哉* \\ 北海道立工業技術センター, 041 函館市桔梗町 379 \\ *信州大学絨維学部, 386 上田市常田 3-15-1

\section{Preparation of $\left(\mathrm{La}_{1-x} \mathrm{Sr}_{x}\right)_{2} \mathrm{MnO}_{4}$ with the $\mathrm{K}_{2} \mathrm{NiF}_{4}$ Structure and its Electrical Properties} \\ Isao SHIMONO and Hajime KONISHI* \\ Hokkaido Industrial Technology Center, 379, Kikyo-cho, Hakodate-shi 041 \\ *Faculty of Textile Science and Technology, Shinshu University, 3-15-1, Tokida, Ueda-shi 386
}

[Received May 6, 1992; Accepted August 21, 1992]

\begin{abstract}
This work was done in order to prepare $\left(\mathrm{La}_{1-x} \mathrm{Sr}_{x}\right)_{2}$ $\mathrm{MnO}_{4}(0.35 \leqq x \leqq 0.65)$ with $\mathrm{K}_{2} \mathrm{NiF}_{4}$ structure and to investigate their electrical properties. The La-rich $\left(\mathrm{La}_{1-x} \mathrm{Sr}_{x}\right)_{2} \mathrm{MnO}_{4}$ has been successfully prepared by a solid-state reaction method in vacuum. The lattice parameters of $\left(\mathrm{La}_{0.5} \mathrm{Sr}_{0.5}\right)_{2} \mathrm{MnO}_{4}$ were the same as those of $\mathrm{La}_{2} \mathrm{CuO}_{4}$. This indicates that the $\mathrm{Mn}-\mathrm{O}$ bond shrank in the $a-b$ plane and the lattice expanded along the $c$-axis in the $\mathrm{K}_{2} \mathrm{NiF}_{4}$ structure by the co-operative Jahn-Teller effect. However, the lattice parameters increased along the $a$-axis and decreased along the $c$-axis as $x$ deviates from $x=0.5$. This tendency differs from that of the $\left(\mathrm{La}_{1-x} \mathrm{Sr}_{x}\right)_{2} \mathrm{CuO}_{4}$ superconductor. The temperature dependence of electrical resistivity of $\left(\mathrm{La}_{1-x}\right.$ $\left.\mathrm{Sr}_{x}\right)_{2} \mathrm{MnO}_{4}$ obeyed the Arrhenius law. The result showed that $\left(\mathrm{La}_{1-x} \mathrm{Sr}_{x}\right)_{2} \mathrm{MnO}_{4}(0.35 \leqq x \leqq 0.65)$ is a semiconductor.
\end{abstract}

Key-words : $\left(\mathrm{La}_{1-x} \mathrm{Sr}_{x}\right)_{2} \mathrm{MnO}_{4}, \mathrm{~K}_{2} \mathrm{NiF}_{4}$ structure, JahnTeller effect, Lattice parameter, Electrical property

\section{1. 緒 言}

Bednorz と Müller による $\mathrm{La}-\mathrm{Ba}-\mathrm{Cu}$ 系酸化物超伝導体 の発見1)がトリガーとなり，Y-Ba-Cu系や $\mathrm{Bi}-\mathrm{Sr}-\mathrm{Ca}-$ $\mathrm{Cu}$ 系を代表とする多くの $\mathrm{Cu}$ 系酸化物超伝導体が見いだ されてきた．これらの超伝導体の構造解析から, 以下のよ うな共通点が知られた。

（1） $\mathrm{Cu}$ 系酸化物超伝導体は，Cuイオンの周囲に酸素 イオンが八面体型又はピラミッド型に配位した単位構造を もっている.この $\mathrm{Cu}-\mathrm{O}$ 多面体は 2 次元的なつながりを 有している2).

(2) $\mathrm{Cu}-\mathrm{O}$ 多面体が 2 次元的につながった平面（ $a-b$ 面）内の $\mathrm{Cu}-\mathrm{O}$ 間結合距離は, $\mathrm{Cu}$ 以外の $3 \mathrm{~d}$ 遷移金属か らなる同様の構造をもつ酸化物と比較して短い。このこと は， $a-b$ 面内で $\mathrm{Cu}$ と $\mathrm{O}$ の共有結合性が強いことを示唆し ている2).

(2)に関連し， $\mathrm{Cu}$ 系酸化物超伝導体は圧力により $T_{\mathrm{c}}$ が 上昇することが知られた ${ }^{3) ~ 5)}$. 圧力効果による $T_{\mathrm{c}}$ の向上 は， $\mathrm{Y}-\mathrm{Ba}-\mathrm{Cu}$ 系の開発指針ともなった．以上の報告は， $a-b$ 面内の $\mathrm{Cu}-\mathrm{O}$ 間結合距離と超伝導特性との間に重要な
関係が存在することを示唆している.

$a-b$ 面内の $\mathrm{Cu}-\mathrm{O}$ 間結合距離が短いのは, $\mathrm{Cu}^{2+}$ がヤー ンテラーイオン6),7)であることが原因となっている. 図 1 (a)に $\mathrm{Cu}^{2+}$ の $3 \mathrm{~d}$ 軌道のエネルギ一準位の概略図を示す. $\mathrm{Cu}^{2+}$ は $3 \mathrm{~d}$ 軌道に 9 個の電子をもっている. $3 \mathrm{~d}$ 軌道の工 ネルギーは, 球対称のポテンシャル場に扔いて 5 重に縮 退している. 頂点を陰イオンとする正八面体がつくりだす ポテンシャル場の中心に $\mathrm{Cu}^{2+}$ を抢いたとき，3d 軌道は 縮退がとけて $\mathrm{E}_{\mathrm{g}}$ 軌道と $\mathrm{T}_{2 \mathrm{~g}}$ 軌道に分裂する.ここで， $x$ 軸上と $y$ 軸上の陰イオンが中心の $\mathrm{Cu}^{2+}$ へ近づき, $z$ 軸上 の陰イオンが $\mathrm{Cu}^{2+}$ から遠ざかると, $\mathrm{E}_{\mathrm{g}}$ 軌道と $\mathrm{T}_{2 \mathrm{~g}}$ 軌道 は更に縮退がとけて分裂する. $\mathrm{Cu}^{2+}$ は $\mathrm{E}_{\mathrm{g}}$ 軌道に 3 個の 電子をもつため, このような八面体の歪はエネルギーの利 得に寄与する。図 1 (b)に $\mathrm{Mn}^{3+}$ の $3 \mathrm{~d}$ 軌道のエネルギー 準位の概略図を示す. $\mathrm{Mn}^{3+}$ は, $\mathrm{Cu}^{2+}$ と同様に $\mathrm{E}_{\mathrm{g}}$ 軌道に 奇数個の電子をもつことから，ヤーンテラーイオンである ことが分かる。

$\mathrm{K}_{2} \mathrm{NiF}_{4}$ 型 $\left(\mathrm{La}_{1-x} \mathrm{Sr}_{x}\right)_{2} \mathrm{MnO}_{4}$ は, $\mathrm{Mn}^{3+}$ の周囲に酸素イ オンが八面体型に配位した単位構造をもつ。したがって, この物質の $a-b$ 面内の $\mathrm{Mn}-\mathrm{O}$ 間結合距離は, $\mathrm{Cu}$ 系之同様 に短( ${ }^{8)}$. 以上の理由から，この物質を合成して物理的特 性を測定することは，超伝導特性を示す $\left(\mathrm{La}_{1-x} \mathrm{Sr}_{x}\right)_{2} \mathrm{CuO}_{4}$ との比較の意味で非常に興味深い. $\left(\mathrm{La}_{1-x} \mathrm{Sr}_{x}\right)_{2} \mathrm{MnO}_{4}$ の 合成や電気特性 - 磁気特性については, $\mathrm{Cu}$ 系酸化物超伝 導体の発見以前にもいくつか報告されている8) 12). しか

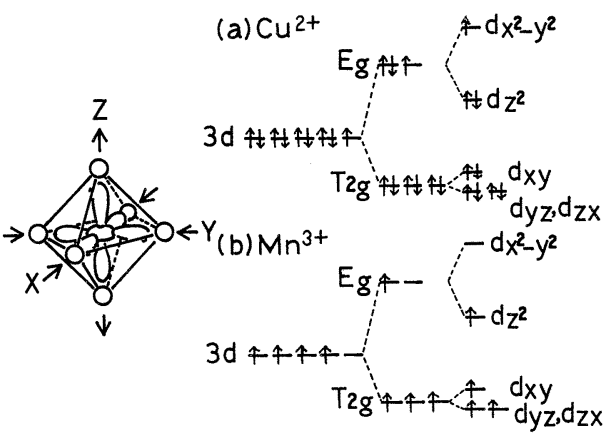

Fig. 1. Schematic energy levels for the $3 \mathrm{~d}$ electrons of $\mathrm{Cu}^{3+}$ and $\mathrm{Mn}^{3+}$ in the octahedral complex. 
し, $\left(\mathrm{La}_{1-x} \mathrm{Sr}_{x}\right)_{2} \mathrm{CuO}_{4}$ で超伝導特性が出現した組成に対応 する $\left(\mathrm{La}_{1-x} \mathrm{Sr}_{x}\right)_{2} \mathrm{MnO}_{4}$ の合成や電気特性・磁気特性に関 する報告はわずかである ${ }^{8), 12)}$. 特に, $a-b$ 面内へのキャリ アのドープが期待される高 $\mathrm{La}$ 濃度側の試料に関しては全 く報告がない。本研究では， $\left(\mathrm{La}_{1-x} \mathrm{Sr}_{x}\right)_{2} \mathrm{MnO}_{4}$ $(0.35 \leqq x \leqq 0.65)$ の合成を行い， La と $\mathrm{Sr}$ の組成比を変化 させた場合の格子定数変化, ならびにその電気特性を測定 した。

\section{2. 実験方法}

出発原料には市販の $\mathrm{La}_{2} \mathrm{O}_{3}, \mathrm{SrCO}_{3}, \mathrm{Mn}_{2} \mathrm{O}_{3}$ （純度99 99.9\%)を用いた。この原料を組成比が $\left(\mathrm{La}_{1-x} \mathrm{Sr}_{x}\right)_{2}$ $\mathrm{Mn}_{1} \mathrm{O}_{y}(x=0.35 \sim 0.65)$ となるように秤量した。組成範 囲は次の理由により決定した. 前述したように $\mathrm{Cu}$ 系のヤー ンテラーイオンは $\mathrm{Cu}^{2+}$ であり，ヤーンテラー歪の生じる 基本物質はチャージバランスから考えて $\mathrm{La}_{2} \mathrm{CuO}_{4}$ とな る. $\left(\mathrm{La}_{1-x} \mathrm{Sr}_{x}\right)_{2} \mathrm{CuO}_{4}$ において, 超伝導特性が出現した組

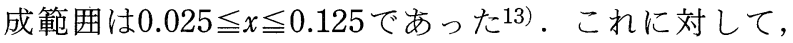
$\mathrm{Mn}$ 系のヤーンテラーイオンは $\mathrm{Mn}^{3+}$ であり，基本物質は $\left(\mathrm{La}_{0.5} \mathrm{Sr}_{0.5}\right){ }_{2} \mathrm{MnO}_{4}$ となる. $\mathrm{Mn}$ の価数を $3+$ よりも小さ くし, $\mathrm{d} x^{2}-y^{2}$ 軌道に電子をドープする目的で基本物質より も $\mathrm{La}$ 量の多い組成 $(0.35 \leqq x<0.5)$ を選んだ。また， $\mathrm{Mn}$ の価数を $3+$ より大きくし, $\mathrm{d} z^{2}$ 軌道にホールを ドープする目的で基本物質よりも $\mathrm{Sr}$ 量の多い組成 $(0.5<x \leqq 0.65)$ を選んだ.

純水を溶媒, ジルコニアボールをかくはん媒体に用いた 湿式ボールミル混合を 15 時間行い, $100^{\circ} \mathrm{C} \times 20$ 時間の乾燥 により混合粉を得た．この混合粉を成形圧力 $1000 \mathrm{~kg} / \mathrm{cm}^{2}$ で直径 $20 \mathrm{~mm}$, 厚さ約 $2 \mathrm{~mm}$ のディスク状に成形し, 空 気中，低真空中（約 $5 \times 10^{-2}$ Torr），高真空中（約 $5 \times$ $10^{-5}$ Torr）の 3 条件で $1300^{\circ} \mathrm{C} \times 20$ 時間の焼成を行った.

一般にセラミックスの製法では, 焼成温度よりも低い温度 における仮焼処理が行われる，本研究では，焼成温度より も低い温度で仮焼を行うと未知の不純物相が生成した.こ の不純物相は $\left(\mathrm{La}_{1-x} \mathrm{Sr}_{x}\right)_{2} \mathrm{MnO}_{4}$ 相の生成を妨げると判断 したため，本研究では仮焼は行わなかった。

各試料に生成した相を同定する目的で, $\mathrm{Cu} \mathrm{K} \alpha$ 線を用 いた X 線回折（XRD）測定を行った。真空中で焼成した 焼結体の表面は白色を呈しており，この白色相は XRD 測 定より $\mathrm{La}_{2} \mathrm{O}_{3}$ 相であることが分かった。そこで，焼結体 の表面をエメリ一紙で除去した後, めのう乳鉢で粉末状に した試料を $\mathrm{XRD}$ 測定に供した. $\mathrm{K}_{2} \mathrm{NiF}_{4}$ 型構造を示した 試料については, Si 粉末を混合した試料を $2 \theta=20^{\circ} \sim 120^{\circ}$ の範囲で XRD 測定し, 内部標準法により格子定数を精密 に求めた．すなわち，試料に混合した Si のピーク角度と 面指数を用いて試料のピーク角度を補正し，その後最小自 乗法を用いて格子定数を精密に計算した。電気抵抗の測定 は, 試料の一片が約 $5 \mathrm{~mm}$ で厚さが約 $1.5 \mathrm{~mm}$ となるよう に加工して, 両面に $\mathrm{Au}$ をスパッタリングして電極を形成 し，直流二端子法で室温から液体窒素温度まで測定した。

\section{3. 結 果}

\section{1 試料の合成}

図 2 に，空気中と低真空中と高真空中で $1300^{\circ} \mathrm{C} \times 20$ 時 間焼成した $x=0.5$ の試料の XRD パターンを示す．空気中 で焼成した試料はペロフスカイト型相と $\mathrm{La}_{2} \mathrm{O}_{3}$ 相と未知 相からなり， $\mathrm{K}_{2} \mathrm{NiF}_{4}$ 型相は全く検出されない， La-Sr$\mathrm{Cu}$ 系酸化物は空気中の焼成により $\mathrm{K}_{2} \mathrm{NiF}_{4}$ 型相の単相を 合成することができると報告されている13),14)． La-Sr$\mathrm{Mn}$ 系酸化物は，空気中での焼成で $\mathrm{K}_{2} \mathrm{NiF}_{4}$ 型相を合成す ることはできないことが分かった．低真空中で焼成した試 料は主相として $\mathrm{K}_{2} \mathrm{NiF}_{4}$ 型相が生成しており，わずかにぺ ロフスカイト型相と思われる回折ピークが見られる．高真 空中で焼成した試料は $\mathrm{K}_{2} \mathrm{NiF}_{4}$ 型相の単相となり，ペロフ スカイト型相の回折ピークは完全に消失していることが分 かる．空気中で焼成した試料を高真空中で $1300^{\circ} \mathrm{C} \times 20$ 時 間再焼成しても，ペロフスカイト型相の回折ピークは完全 には消失せず，図 $2(\mathrm{~b})$ と同様な XRD パターンが得られ た.

以上の結果に基づき，他の組成の試料については空気中 の焼成を行わずに，低真空中と高真空中の焼成を行った。 $\mathrm{Sr}$ 濃度を変えて低真空中及び高真空中焼成した試料の生 成相を表 1 に示す．低真空中で焼成した試料ではすべて少 量のペロフスカイト型相の生成が認められた。 また，高 $\mathrm{Sr}$ 濃度側では未知相の生成も認められた，一方，高真空 中で焼成した試料では, 最も $\mathrm{Sr}$ 濃度の高い $\left(\mathrm{La}_{0.35} \mathrm{Sr}_{0.65}\right)_{2}$ $\mathrm{Mn}_{1} \mathrm{O}_{y}$ の試料を除き $\mathrm{K}_{2} \mathrm{NiF}_{4}$ 型単相を合成できた．以上の 結果から，ペロフスカイト型相などの不純物相の生成を抑 制し，単相の $\mathrm{K}_{2} \mathrm{NiF}_{4}$ 型 $\mathrm{La}-\mathrm{Sr}-\mathrm{Mn}$ 系酸化物を合成する ためには，低酸素分圧下すなわち高真空での焼成が肝要で あることが分かった。

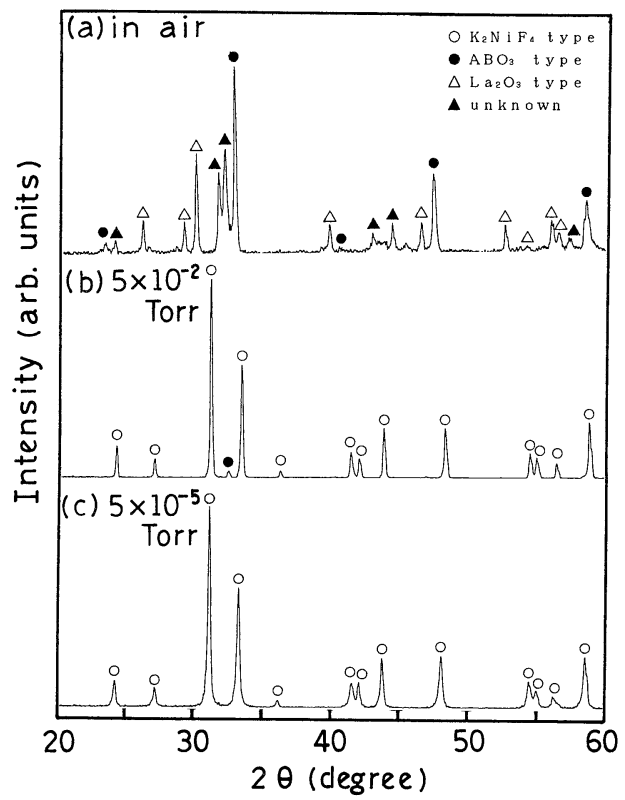

Fig. 2. XRD patterns for the $\left(\mathrm{La}_{0.5} \mathrm{Sr}_{0.5}\right){ }_{2} \mathrm{MnO}_{y}$ samples sintered at $1300^{\circ} \mathrm{C}$ for $20 \mathrm{~h}$ in (a) air, (b) $5 \times 10^{-2}$ Torr and (c) $5 \times 10^{-5}$ Torr. 
Table 1. Detected phases in the samples with different compositions.

\begin{tabular}{|c|c|c|c|c|c|c|}
\hline \multirow{2}{*}{$\begin{array}{l}\text { Nominal } \\
\text { La }\end{array}$} & \multicolumn{2}{|c|}{ Composition } & \multirow{2}{*}{$\begin{array}{l}\text { Sintering } \\
\text { Condition }\end{array}$} & \multicolumn{3}{|c|}{ Detected Phases } \\
\hline & $\mathrm{Sr}$ & $M n$ & & $\mathrm{~K}_{2} \mathrm{NiF}_{4}$ & $\mathrm{ABO}_{3}$ & unknown \\
\hline 1.3 & 0.7 & 1.0 & & () & $\triangle$ & \\
\hline 1.2 & 0.8 & 1. 0 & & (1) & $\Delta$ & \\
\hline 1.1 & 0.9 & 1. 0 & & (a) & $\Delta$ & \\
\hline 1.0 & 1.0 & 1.0 & $1300^{\circ} \mathrm{C} \times 20 \mathrm{~h}$ & (a) & $\Delta$ & \\
\hline 0.9 & 1.1 & 1. 0 & $5 \times 10^{-2}$ Torr & (0) & $\Delta$ & \\
\hline 0.8 & 1.2 & 1.0 & & (2) & & $\triangle$ \\
\hline 0.7 & 1.3 & 1. 0 & & () & & $\triangle$ \\
\hline 1.3 & 0.7 & 1.0 & & () & & \\
\hline 1.2 & 0.8 & 1.0 & & () & & \\
\hline 1.1 & 0.9 & 1.0 & & () & & \\
\hline 1.0 & 1.0 & 1. 0 & $1300^{\circ} \mathrm{C} \times 20 \mathrm{~h}$ & () & & \\
\hline 0.9 & 1.1 & 1. 0 & $5 \times 10^{-5}$ Torr & () & & \\
\hline 0.8 & 1.2 & 1.0 & & () & & \\
\hline 0.7 & 1.3 & 1. 0 & & () & & $\Delta$ \\
\hline
\end{tabular}

( (0):Strong, $\triangle$ : Keak; $\mathrm{ABO}_{3}=$ Perovskite type)

\section{2 試料の走査型電子顕微鏡観察}

図 3 K，高真空中で焼成した代表的組成の焼結体破断面 の走查型電子顕微鏡 $(\mathrm{SEM})$ 像を示す. $\left(\mathrm{La}_{0.65} \mathrm{Sr}_{0.35}\right)_{2}$ $\mathrm{MnO}_{4}$ の焼結体は緻密であり, 結晶粒径も大きいことが分 かる. Sr 濃度が高くなるに従い焼結体は多孔質となり， 結晶粒径も小さくなる傾向を示す。これらの焼結体を XRD 測定に供するためにめのう乳鉢による粉砕を行った が，高 $\mathrm{La}$ 濃度の焼結体ほど粉砕が困難であった。

\section{3 格子定数の組成依存性}

図 4 に低真空焼成及び高真空焼成した試料の $\mathrm{K}_{2} \mathrm{NiF}_{4}$ 型 相の $\mathrm{Sr}$ 濃度による格子定数変化を示す. 図 4 中には Kanbe らにより求められた $\mathrm{Sr}$ 濃度による $\left(\mathrm{La}_{1-x} \mathrm{Sr}_{x}\right)_{2}$ $\mathrm{CuO}_{4}$ の格子定数変化吕) を, $\mathrm{La}_{2} \mathrm{CuO}_{4}$ と $\left(\mathrm{La}_{0.5} \mathrm{Sr}_{0.5}\right)_{2}$ $\mathrm{MnO}_{4}$ が同じ横軸上の位置となるようにプロットした。 $\left(\mathrm{La}_{0.5} \mathrm{Sr}_{0.5}\right)_{2} \mathrm{MnO}_{4}$ の格子定数は $\mathrm{La}_{2} \mathrm{CuO}_{4}$ とほぼ同一值を 示しており， $a-b$ 面内の $\mathrm{Mn}-\mathrm{O}$ 間結合距離は $\mathrm{Mn}^{3+}$ の ヤーンテラー効果により $\mathrm{La}_{2} \mathrm{CuO}_{4}$ と同等に短いことが分 かる.ここで得られた $\mathrm{Mn}$ 系の格子定数は，Blasseによ り求められた格子定数 $(a=3.88 \AA, c=12.5 \AA, c / a=3.2)^{9)}$ とは一致せずに, Benabad らにより求められた格子定数 $(a=3.804 \AA, c=13.10 \AA, c / a=3.445)^{8)}$ と良い一致を示し た. $c / a$ 值の小さい試料は, 酸素過剩型の非化学量論組成

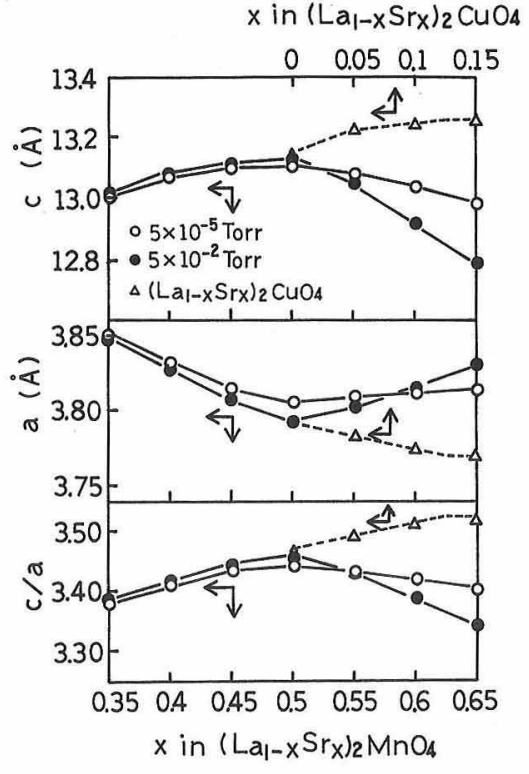

Fig. 4. Sr composition $x$ in $\left(\mathrm{La}_{1-x} \mathrm{Sr}_{x}\right)_{2} \mathrm{MnO}_{4}$ dependence of the lattice parameters $a, c$ and $c / a$. The data for $\left(\mathrm{La}_{1-x} \mathrm{Sr}_{x}\right)_{2} \mathrm{CuO}_{4}$ was reported by Kanbe et al. ${ }^{13)}$

であると考えられている15)。一方，Benabad らの合成し た試料は化学量論組成であり, $c / a$ 值が大きいと報告され ている8),15)。本研究で合成した試料は，Benabad らが合 成した試料と同様に $c / a$ 值が大きいことから, 化学量論組 成に近い組成を有しているものと考えられる。この $\left(\mathrm{La}_{0.5} \mathrm{Sr}_{0.5}\right)_{2} \mathrm{MnO}_{4}$ を中心として高 $\mathrm{La}$ 濃度，高 $\mathrm{Sr}$ 濃度と なるに従い, $a$ 軸長は長く, $c$ 軸長は短くなる傾向を示す ことが分かる. 高 $\mathrm{Sr}$ 濃度側で高真空焼成した試料と低真 空焼成した試料の格子定数が異なっているのは，未知相の 生成により仕込んだ元素の一部が $\mathrm{K}_{2} \mathrm{NiF}_{4}$ 型相の生成に寄 与しなかったためと考えられる。

\section{4 電気的特性}

図 5 に高真空中で焼成した代表的試料の電気抵抗の温度 依存性を示す。 3 試料とも，温度の低下とともに電気抵抗 が増大する半導体的挙動を示していることが分かる。本実 験で作製したすべての試料はこのような半導体的挙動を示 した. 高 Sr 濃度側の試料が半導体的挙動を示すことは, これまでにも報告されている11),12)。本実験結果からは， $a-b$ 面内へのキャリアのドープが期待される高 $\mathrm{La}$ 濃度側
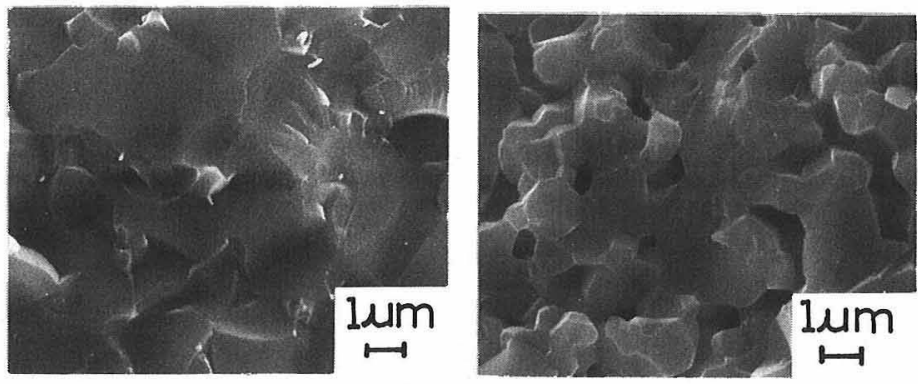

(b) $\left(\mathrm{La}_{0.5} \mathrm{Sr}_{0.5}\right)_{2} \mathrm{MnO}_{4}$

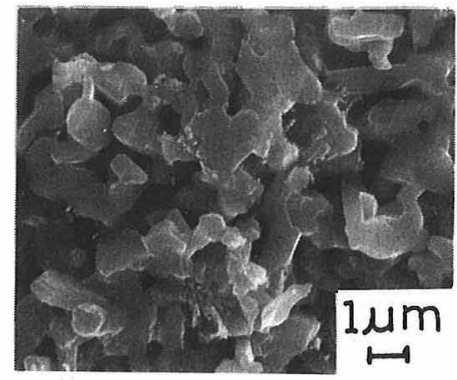

(c) $\left(\mathrm{La}_{0.35} \mathrm{Sr}_{0.65}\right)_{2} \mathrm{MnO}_{4}$

Fig. 3. SEM photographs of the fractured cross section of the pellets sintered at $1300^{\circ} \mathrm{C}$ for $20 \mathrm{~h}$ in $5 \times 10^{-5}$ Torr. 


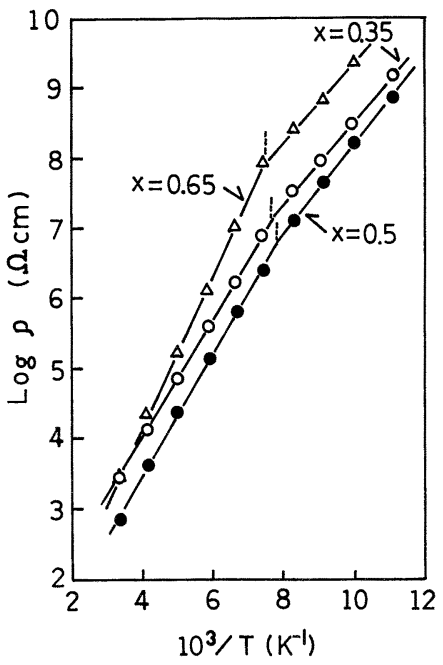

Fig. 5. Temperature dependence of electrical resistivity for the samples $x=0.35,0.5$ and 0.65 in $\left(\mathrm{La}_{1-x} \mathrm{Sr}_{x}\right)_{2} \mathrm{MnO}_{4}$ sintered at $1300^{\circ} \mathrm{C}$ for $20 \mathrm{~h}$ in $5 \times 10^{-5}$ Torr.

の試料に関しても， $\left(\mathrm{La}_{1-x} \mathrm{Sr}_{x}\right)_{2} \mathrm{CuO}_{4}$ の超伝導遷移前にみ られるような金属的挙動は示さないことが知られた。

図 5 において $130 \mathrm{~K}$ 付近を境として直線の勾配が变化 している．このような勾配の変化は，低真空中で焼成した $\left(\mathrm{La}_{0.6} \mathrm{Sr}_{0.4}\right)_{2} \mathrm{MnO}_{4}$ を除きすべての試料でみられた。この 勾配から，次式を用いて見掛けの活性化エネルギー $\Delta E$ を 求めた.

$$
\begin{aligned}
& \ln \rho=B \cdot(1 / T)+A \\
& \Delta E=2 k B
\end{aligned}
$$

ここで, $\rho:$ 比抵抗

$$
\begin{aligned}
& A, B: \text { 定数 } \\
& k: \text { ボルツマン定数 }
\end{aligned}
$$

図 6 K $\Delta E$ の組成 $x$ 依存性を示す。低温側の $\Delta E$ は $0.2 \sim$ $0.3 \mathrm{eV}$ と組成に依存せずほぼ一定值を示している。高温 側の $\Delta E$ は $0.3 \mathrm{eV}$ から $0.45 \mathrm{eV}$ まで $\mathrm{Sr}$ 濃度の増加ととも に増加する傾向を示している. 低温側の $\Delta E$ の物理的意味 は，不純物により形成されたエネルギー準位，磁気特性の 変化に関するものなどが考えられる，詳細については，今

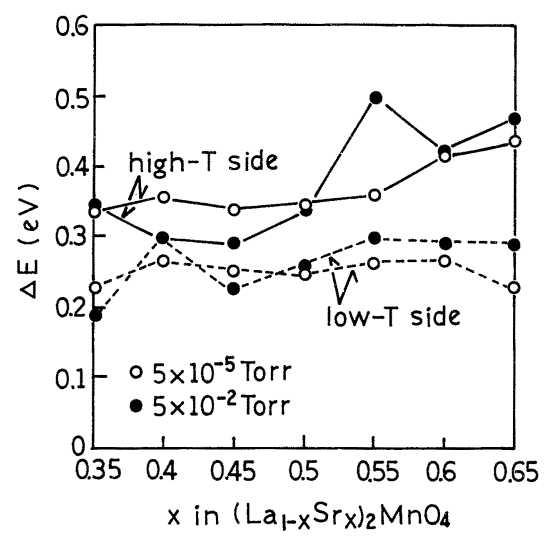

Fig. 6. Sr composition $x$ in $\left(\mathrm{La}_{1-x} \mathrm{Sr}_{x}\right)_{2} \mathrm{MnO}_{4}$ dependence of the activation energy calculated from the high-temperature side and the low-temperature side of Fig. 5.
後更に研究を推進する予定である.

\section{4. 考 察}

超伝導特性を示す $\left(\mathrm{La}_{1-x} \mathrm{Sr}_{x}\right)_{2} \mathrm{CuO}_{4}$ では， $\mathrm{La}$ サイトを $\mathrm{Sr}$ で置換することにより更に $a$ 軸長が短く,$c$ 軸長が長く なり, ヤーンテラー効果による結晶格子歪が助長されるこ とが知られている13)。すなわち， Cu系では Laサイトの $\mathrm{Sr}$ 置換により生成した $\mathrm{Cu}^{3+}$ の $\mathrm{E}_{\mathrm{g}}$ 軌道に存在する 2 個の 電子はフントの法則に従わず，共に $\mathrm{d} z^{2}$ 軌道に入る. した がって, $\mathrm{d} x^{2}-y^{2}$ 軌道は空になり, ホールが形成されると考 えられる．この結晶化学的見地加ら考察された電子配置 は, $\left(\mathrm{La}_{1-x} \mathrm{Sr}_{x}\right)_{2} \mathrm{CuO}_{4}$ の単結晶に関する光学的研究加ら推 測された，高温超伝導はキャリアがドープされた $\mathrm{CuO}_{2} 2$ 次元面で起こる，という考光16)を支持する.

一方, 本研究で知られた $\left(\mathrm{La}_{1-x} \mathrm{Sr}_{x}\right)_{2} \mathrm{MnO}_{4}$ の $x$ による 格子定数変化の傾向は, 図 1 (b) に示す $\mathrm{Mn}^{3+}$ のエネル ギー準位図を用い，次のように説明することができる．

$\left(\mathrm{La}_{0.5} \mathrm{Sr}_{0.5}\right)_{2} \mathrm{MnO}_{4}$ は含まれる $\mathrm{Mn}$ イオンのすべてが $\mathrm{Mn}^{3+}$ であり, ヤーンテラー効果による結晶格子歪が最も 大きい. 高 $\mathrm{La}$ 濃度側では $\mathrm{Mn}$ イオンの一部が $\mathrm{Mn}^{2+}$ とな る. また, 高 $\mathrm{Sr}$ 濃度側では $\mathrm{Mn} イ$ オンの一部が $\mathrm{Mn}^{4+}$ と なる. $\mathrm{Mn}^{2+}$ の $\mathrm{E}_{\mathrm{g}}$ 軌道は電子が 2 個存在し, $\mathrm{Mn}^{4+}$ の $\mathrm{E}_{\mathrm{g}}$ 軌道は電子が 0 個である. $\mathrm{Mn}$ 系では $\mathrm{Cu}$ 系とは異なり, $\mathrm{E}_{\mathrm{g}}$ 軌道の電子はフントの法則に従って配置するため, い ずれの場合もヤーンテラー効果による結晶格子歪は徐々に 緩和されていく．したがって，( $\left(\mathrm{La}_{0.5} \mathrm{Sr}_{0.5}\right)_{2} \mathrm{MnO}_{4}$ を中心 として高 $\mathrm{La}$ 濃度, 高 $\mathrm{Sr}$ 濃度となるに従い, $a$ 軸長は長 $く, c$ 軸長は短くなる傾向を示す.

$\mathrm{Mn}$ 系の格子定数变化から考察された電子配置より, 試 料には電子とホールがドープされたものと考えられる.し かし, Mn 系の電気的特性は全試料において金属的挙動を 示さなかった. 表 2 に, 試料の一端を加熱して発生する熱 起電力の極性から求めたキャリアのタイプを示す. 表 2 中には, 組成のチャージバランスから推定されるキャリア のタイプも示した. 組成のチャージバランスから推定され るキャリアのタイプと, 熱起電力の極性から求めたキャリ アのタイプは一致していないことが分かる.このことは, $x$ を変化させたときに生成する電子やホールは，Mnイオ ンに局在し，電気伝導には寄与していないことを示唆して いる.Mnイオンに局在せずに電気伝導に寄与しているの は，結晶中に存在するわずかなイオン欠損が原因で生成し

Table 2. Carrier-type of $\left(\mathrm{La}_{1-x} \mathrm{Sr}_{x}\right)_{2} \mathrm{MnO}_{4}$ estimated from the polarity of the thermoelectric power.

\begin{tabular}{cccc}
\hline \hline $\begin{array}{l}\mathrm{x} \text { in } \\
\left(\mathrm{La}_{1-\mathrm{SS}}\right)_{2} \mathrm{KnO}_{4}\end{array}$ & $\begin{array}{c}1300^{\circ} \mathrm{C} \times 2 \mathrm{OH} \\
5 \times 10^{-2} \text { Torr }\end{array}$ & $\begin{array}{c}1300^{\circ} \mathrm{C} \times 2 \mathrm{OH} \\
5 \times 10^{-5} \text { Torr }\end{array}$ & $\begin{array}{c}\text { estimation from } \\
\text { the charge balance }\end{array}$ \\
\hline 0.35 & $\mathrm{p}$ & $\mathrm{p}$ & $\mathrm{n}$ \\
0.40 & $\mathrm{n}$ & $\mathrm{n}$ & $\mathrm{n}$ \\
0.45 & $\mathrm{n}$ & $\mathrm{n}$ & $\mathrm{n}$ \\
0.50 & $\mathrm{n}$ & $\mathrm{n}$ & - \\
0.55 & $\mathrm{n}$ & $\mathrm{n}$ & $\mathrm{p}$ \\
0.60 & $\mathrm{n}$ & $\mathrm{n}$ & $\mathrm{p}$ \\
0.65 & $\mathrm{p}$ & $\mathrm{n}$ & $\mathrm{p}$ \\
\hline \hline
\end{tabular}


たキャリアではないかと考えられる.

\section{5. 結 言}

固相反応法により $\left(\mathrm{La}_{1-x} \mathrm{Sr}_{x}\right)_{2} \mathrm{MnO}_{4}$ の合成を行った. 混合粉からなる成形体を，仮焼せずに，高真空中で焼成す ることにより,$x=0.35 \sim 0.6$ の範囲で $\left(\mathrm{La}_{1-x} \mathrm{Sr}_{x}\right)_{2} \mathrm{MnO}_{4}$ 単相が合成できた. $\left(\mathrm{La}_{0.5} \mathrm{Sr}_{0.5}\right)_{2} \mathrm{MnO}_{4}$ の格子定数は $\mathrm{La}_{2}$ $\mathrm{CuO}_{4}$ の格子定数とほぼ同一值を示した。 $\left(\mathrm{La}_{0.5} \mathrm{Sr}_{0.5}\right)_{2}$ $\mathrm{MnO}_{4}$ を中心として高 $\mathrm{La}$ 濃度, 高 $\mathrm{Sr}$ 濃度となるに従い $a$ 軸長は長く, $c$ 軸長は短くなる傾向を示した。 $\left(\mathrm{La}_{1-x} \mathrm{Sr}_{x}\right)_{2} \mathrm{MnO}_{4}$ の $x$ による格子定数变化の傾向は, ヤーンテラー効果の緩和により説明できた.すべての試料 の電気的特性は, 温度の低下とともに電気抵抗が増大する 半導体的挙動を示した.

謝辞 本研究を推進するに当たり, 北海道立工業技術セン ターの加賀 寿科長, 高村 巧主任, 室蘭工大の濱口由和教授に は様々な形でご援助頂いた。 また実験には, 信州大学瀻維学研究 科大学院生の岩下弘幸氏の協力を得た.ここに, 心から感謝の意 を表す。

（1990年 9 月，日本セラミックス協会第 3 回秋季シンポジウム にて一部発表)

\section{文 献}

1) J. G. Bednorz and K. A. Müller, Z. Phys. B., 64, 189-93 (1986).

2）川合知二, 固体物理, 24, 102-12 (1989).

3) M. Kurisu, H. Kadomatsu, H. Fujiwara, Y. Maeno and T. Fujita, Jpn. J. Appl. Phys., 26, L361-62 (1987).

4) H. Takahashi, C. Murayama, S. Yomo, N. Mouri, K. Kishino, K. Kitazawa and K. Fueki, Jpn. J. Appl. Phys, 26, L50405 (1987).

5) N. Terada, H. Ihara, M. Hirabayashi, K. Senzaki, Y. Kimura, K. Murate, M. Tokumoto, O. Shimomura and T. Kikegawa, Jpn. J. Appl. Phys., 26, L510-11 (1987).

6) J. D. Dunitz and L. E. Orgel, J. Phys. Chem. Solids, 3, 20-29 (1957).

7）大西晴幸，寺西英夫，金属物理，7, 153-67 (1961).

8) A. Benabad, A. Daoudi, R. Salomon and G. Le Flem, J. Solid State Chem., 22, 121-26 (1977).

9) G. Blasse, J. Inorg. Nucl. Chem., 27, 2683-84 (1965).

10) J. B. MacChesney, J. F. Potter and R. C. Sherwood, J. Appl. Phys., 40, 1243-45 (1969).

11) J. C. Bouloux, J. L. Soubeyroux, A. Daoudi and G. L. Flem, Mat. Res. Bukk., 16, 855-60 (1981).

12) R. A. MohanRam, P. Gauguly and C. N. R. Rao, J. Solid State Chem., 70, 82-87 (1987).

13) S. Kanbe, K. Kishino, K. Kitazawa, K. Fueki, H. Takagi and S. Tanaka, Chem. Lett., 547-50 (1987).

14) K. Oh-ishi, M. Kikuchi, Y. Syono, K. Hiraga and Y. Morioka, Jpn. J. Appl. Phys., 26, L484-87 (1987).

15) P. Ganguly and C. N. R. Rao, J. Solid State Chem., 53, 19216 (1984).

16）内田慎一, 固体物理, 25, 690-700 (1990). 